\title{
ТРАНЗИСТОРНИЙ ВИМІРЮВАЛЬНИЙ ПЕРЕТВОРЮВАЧ БІОМЕДИЧНОГО ДИФЕРЕНЦІЙНОГО СКАНУЮЧОГО КАЛОРИМЕТРА
}

\author{
Р. Л. Голяка, О. В. Бойко, Н. В. Дорош, В. Ю. Ільканич \\ Львівський національний медичний університет ім. Д. Галицького \\ Національний університет «Львівська політехніка»
}

\begin{abstract}
Based on transistors the measurement transducer for biomedical differential scanning calorimetry sensor is proposed. The differential temperature measurements are provided by a differential $n-p-n$ transistor stage and an ADuC834 24-Bit MicroConverter. The circuit and software of the sensor device developed are described. The main features of the sensor are: difference temperature measurement ranges $-A) \pm 10^{\circ} \mathrm{C}$, B) $\pm 30^{\circ} \mathrm{C}$; difference temperature measurement resolution better than $0,001^{\circ} \mathrm{C}$; temperature measurement ranges - from $40^{\circ} \mathrm{C}$ to $100^{\circ} \mathrm{C}$; supply voltage $-5 \mathrm{~V} \pm 10 \%$; interface $-\mathrm{USB}$.
\end{abstract}

Диференціальна скануюча калориметрія (ДСК) базується на вимірюванні кількості енергії, поглиненої або виділеної зразком, при неперервному підвищенні чи зниженні температури. Цей метод є одним 3 найефективніших способів структурного аналізу, включаючи визначення області склування, значення температур плавлення й кристалізації, фазових переходів полімерів, температури термічної деструкції тощо. Застосування методу ДСК також дозволяє судити про наявність або відсутність антиоксиданта в полімері, антистатиків, поглиначів ультрафіолетового випромінювання, модифікаторів ударної міцності матеріалу [1]. Серед сучасних пристроїв, що забезпечують автоматизацію ДСК $\epsilon$, зокрема, диференційний скануючий калориметр Diamond DSC компанії PerkinElmer. Первинними вимірювальними перетворювачами таких пристроїв $\epsilon$ терморезистори або термопари [2].

За останній час ДСК знайшла своє використання в сенсорах біомедичного призначення. 3 їх допомогою проводять якісний та кількісний аналіз фармацевтичних засобів, білків, кісткової тканини, м'язів тощо [3, 4]. На жаль, існуючі пристрої ДСК не в повній мірі відповідають вимогам біомедичної сенсорики. Особливістю останньої є необхідність зменшення мінімально допустимої маси досліджуваної речовини (до декількох грам і менше), підвищення точності вимірювання, а також, відповідність вимогам сучасної біомедичної мікроелектроніки.

В рамках даної роботи вирішена задача підвищення експлуатаційних характеристик ДСК біомедичного призначення шляхом заміни вищезгаданих терморезисторів чи термопар на транзисторні вимірювальні перетворювачі. Сучасні транзистори характеризуються гранично малими розмірами (від декількох мікрометрів і до міліметра), а сигнальні перетворювачі диференційних термометрів на їх ос- нові, що реалізуються схемою диференціального каскаду, забезпечують суттєво вищу, у порівнянні з терморезисторами чи термопарами, температурну чутливість [5].

Диференційний каскад описується системою рівнянь

$$
\left\{\begin{array}{l}
I_{C 1}=\alpha_{1} I_{E 1} \\
I_{C 2}=\alpha_{2} I_{E 2} \\
I_{E 1}+I_{E 2}=I_{\Sigma E}
\end{array},\right.
$$

де: $\mathrm{I}_{\mathrm{Cl}}, \mathrm{I}_{\mathrm{El}}$ - колекторний та емітерний струми транзистора $\mathrm{T}_{1} ; \mathrm{I}_{\mathrm{C} 2}, \mathrm{I}_{\mathrm{E} 2}$ - аналогічно для транзистора $\mathrm{T}_{2}$; $\mathrm{a}_{1}, \mathrm{a}_{2}$-коефіцієнти передачі струму цих транзисторів (типово а $=0,99 . .0,995) ; \quad I_{E 1}=I_{S E 10} \exp \left(\frac{V_{B E 1}}{m_{1} \varphi_{T}}-1\right)$; $I_{E 2}=I_{S E 20} \exp \left(\frac{V_{B E 2}}{m_{2} \varphi_{T}}-1\right)-$ залежності емітерних струмів транзисторів від напруги $\mathrm{V}_{\mathrm{BE} 1}, \mathrm{~V}_{\mathrm{BE} 2}$ їх емітерно-базових p-n переходів; $\mathrm{I}_{\mathrm{SE} 10}, \mathrm{I}_{\mathrm{SE} 20}, \mathrm{~m}_{1}, \mathrm{~m}_{2}$-відповідно, струми насичення та коефіцієнти неідеальності цих р-п переходів; $\varphi_{T}=k T / q$-температурний потенціал; $\mathrm{k}$ - стала Больцмана; $\mathrm{T}$ - абсолютна температура; q - заряд електрона; $\mathrm{IS}_{\mathrm{E}}$ - сумарний струм, що втікає в емітерні p-n переходи транзисторів і типово задається або стабілізуючим резистором емітерних кол транзисторів, або джерелом стабільного струму в цих колах.

Інформативним сигналом різниці температур диференціального каскаду є різниця колекторних струмів $\mathrm{DI}_{\mathrm{C}}(\mathrm{T})=\mathrm{I}_{\mathrm{C} 2}(\mathrm{~T})-\mathrm{I}_{\mathrm{Cl}}(\mathrm{T})$ транзисторів, що обумовлена відповідною різницею їх температур. Температурно залежними параметрами транзисторів, що визначають інформативний сигнал $€ \mathrm{I}_{\mathrm{SE} 0}(\mathrm{~T}), \mathrm{j}_{\mathrm{T}}(\mathrm{T}), \mathrm{a}(\mathrm{T})$.

( ) Р. Л. Голяка, О. В. Бойко, Н. В. Дорош, В. Ю. Ільканич 
Диференційний каскад розробленого в рамках роботи транзисторного вимірювального перетворювача біомедичного диференційного скануючого калориметра побудовано на n-p-n транзисторах у мікрокорпусному конструктиві SOT23 з розмірами приблизно 1 х 2 х 3 (мм). Для дослідження параметрів транзистори змонтовані на зонди, зовнішній вигляд яких наведено на рисунку 1.3 метою подальшого зменшення розмірів можуть використовуватися безкорпусні транзистори у «підвішеному» конструктивному виконанні чи з MEMs конструктивнотехнологічий базис, зокрема мембранну конструкцію структури.

Функціональна блок-схема вимірювального перетворювача наведена на рисунку 2 , а його програмне забезпечення - на рисунку 3. Крім диференційного каскаду (транзистори T1, T2, резистори R1, R2, R3) в склад вимірювального перетворювача входить сигнальний підсилювач (операційні підсилювачі OA1, $\mathrm{OA}$, резистори R4, R5, R6), 24-розрядний аналогоцифровий перетворювач з вбудованим мікроконтролером типу ADuC834 (24-Bit MicroConverter), USB інтерфейс (USB Interface) та персональний комп'ютер (PC).

Основними експлуатаційними характеристиками розробленого транзисторного вимірювального пере-

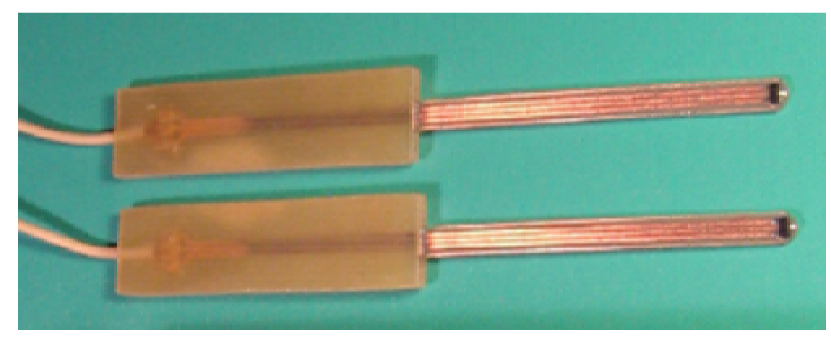

Puc. 1. Зонди диференційного скануючого калориметра.

\section{Література}

1.Behme Robert Heat of Fusion measurement of a low melting polymorph of carbamazepine that undergoes multiple phase changes during DSC analysis / Behme Robert, Brooke Dana / / J. Pharm Sci.-2006. - Vol 80. - Issue 10. - P. 986-990.

2.Bruce Cassel Modulated Temperature DSC and the DSC 8500: A Step Up in Performance / Bruce Cassel, Robert Packer // PerkinElmer, Inc. http://las.perkinelmer.com/.

3.Левицкий Д. И. Применение метода дифференциальной сканирующей калориметрии для структурно-функциональных исследований мышечных белков // Успехи биоло-

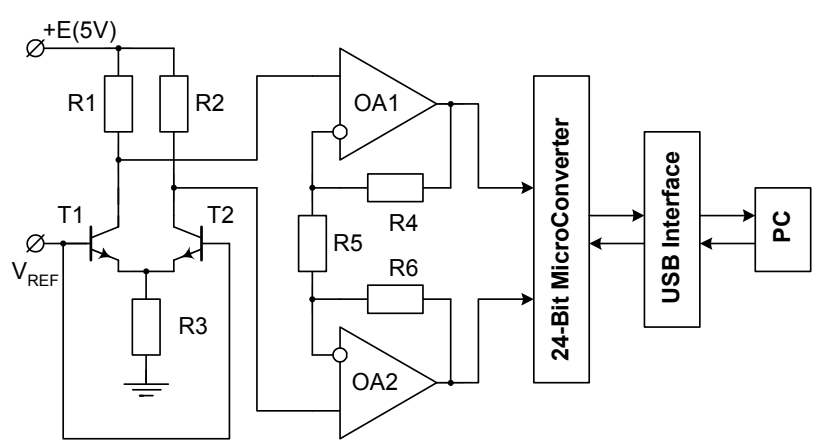

Puc. 2. Функціональна блок-схема вимірювального перетворювача.

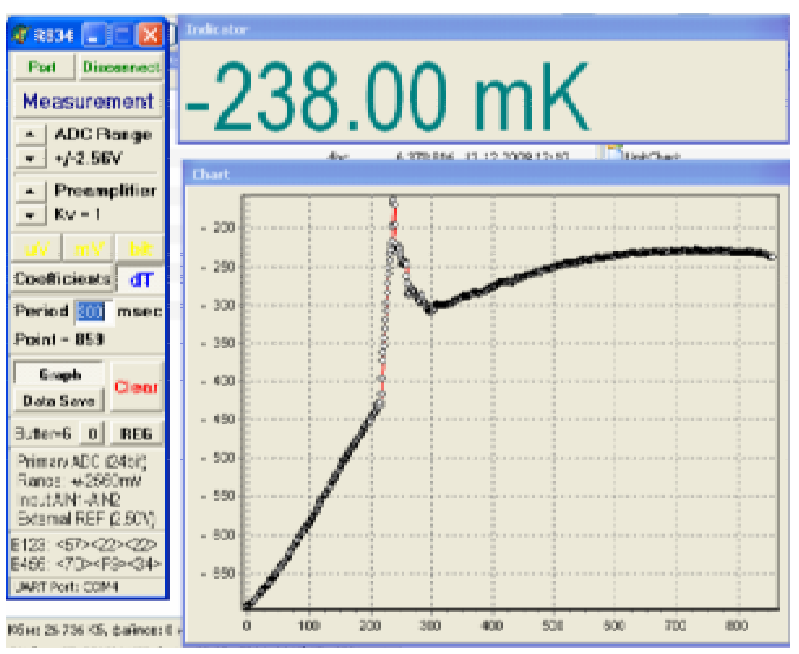

Puc. 3. Вид програмного забезпечення диференційного скануючого калориметра.

творювача $є$ : діапазон вимірювання різниці температур: А) $\pm 10^{\circ} \mathrm{C}$, Б) $\pm 30^{\circ} \mathrm{C}$; роздільна здатність вимірювання різниці температур: не гірше $0,001^{\circ} \mathrm{C}$; робочий діапазон: від мінус $40^{\circ} \mathrm{C}$ до плюс $100^{\circ} \mathrm{C}$; напруга живлення: 5 B $\pm 10 \%$; інтерфейс: USB.

гической химии. - 2004-Т. 44-С.133-170.

4. Жнякина Л. Е. Система дифференциальной сканирующей калориметрии для исследования лекарственных объектов /Жнякина Л.Е., Мощенский Ю.В., Ткаченко М. Л. // Химико-фармацевтический журнал - 2005. - № 11. C. $46-49$.

5.Дифференциальный термометр с высокой разрешающей способностью / Готра 3. Ю., Голяка Р. Л., Павлов С. В. [и др.] // Технология и конструирование в электронной аппаратуре-2009 -№ 6-C. 19-23. 